\title{
Innovation of Teaching Method for Improvement of Higher Education Teaching Quality Lin Lin ${ }^{1, a}$, Yuzhu Han², b \\ ${ }^{1}$ Institute for Higher Education, Jilin Agricultural University,Changchun,130118, China, 2 Jilin Agricultural University, Changchun, 130118, China \\ aemail: linlinjlau@126.com, bemail:linlinjlau@126.com
}

Keywords: Teaching quality; Innovation of teaching methods; Faculty team

\begin{abstract}
Innovation of teaching method is an important way to realize objective of personnel cultivation for universities, of which, features and advantages are fully embodied by the teaching quality. In order to guide innovation of teaching methods of universities and improve their teaching quality, this paper elaborates the specific measures for innovation of teaching methods and improvement of the teaching quality of colleges on the basis of studying limitations of the existing teaching methods of institutions of higher learning.
\end{abstract}

\section{Teaching Method is the Key of Teaching Quality in Higher Education}

The existing most typical and most influential teaching method for higher education is the teachers and students constituting a teaching body, in which, teachers present themselves on the platform and students act as audience or listeners. In that case, knowledge or information is in one-way flow from teachers to students. Under such teaching model, how do we evaluate teaching quality? That is dependent on the degree of students' acquisition of knowledge. To be specific, the more knowledge the students acquire in a more detailed way, and the more consistent the knowledge is with what is taught by teachers and recorded in textbooks, the higher the teaching quality is. From a perspective of international comparison, it is rare to simply adopt such teaching method alone in the world for it is quite laggard and lacks students' subjectivity, teaching interactivity and buildability of knowledge. As such, teaching method is the key of teaching quality of higher education and it is necessary to innovate teaching method for the purpose of improving teaching quality.

\section{Teaching method and Educational Concept for the Course Integrative Studies of Massey University}

Integrative Studies is the last course for the third year undergraduates majoring in agronomy in Massey University before graduation, and is described as "an integrative paper designed to emphasis the importance of the broad knowledge base gained in the degree and the value of multidisciplinary teams in addressing the issues and problems of importance to the industries served by the degree "by the course team. The teaching method and process are:

\subsection{Putting forward reasonable projects}

All the projects are established in line with the actual need of producers, enterprises, scientific research and the market, and are provided with a principal and faculty adviser. Students can choose any project they are interest in.

Based on actual needs, the projects cover a wide range, enable learning to be more intuitive and vivid, and can help stimulate students' original cognitive structure, experience and representation. Therefore, by accomplishing the projects, students are provided with an ideal platform for connection and expansion of old and new knowledge and fully exercise their ability of integrated use of the knowledge exclusive to their major and even interdisciplinary knowledge. 


\subsection{Establishing interaction model}

Students and teachers jointly set up project groups according to the features of projects and students, so that all group members can complement each other's advantages, and cooperate with each other. On this basis, benign interaction among students and teacher, and group members are carried out ${ }^{\text {[1] }}$.

Teachers can combine several teaching methods or ways of communication to increase interaction with students and keep such interaction after class at any time. During project implementation, project members in a same group share resources to obtain the most information, and question thoughts of each other and make explanations, in this way, they not only integrate knowledge but also exercise their organizing ability and communicative competence.

\subsection{Implementing real-time process control}

After assigning projects to students at the beginning of the course, teachers shall notice in advance students of the project deadline according to the teaching program and follow up with the progress of each project group by minutes of meeting. During report of all the project groups after completion of projects, teachers shall provide guidance for the important and difficult points and deficiencies top ensure the best teaching results.

\subsection{Improving assessment system}

Course assessment is carried out from multiple dimensions, including 7 items such as individual and project group scoring, group discussion, oral report, written report etc. Each item accounts for different score percentage to completely eradicate the traditional standard of the unique importance of examination. Formative assessment is the focus on, referring to evaluation of the attitude, knowledge level, comprehensive abilities of students exhibited during project implementation based on improvement of abilities and project achievements of students.

The teaching method employed in the course Integrative Studies of Massey University is based on projects, oriented on students and directed by teachers can be called by different education doctrines or theories as "project/task-driven teaching method", "participatory teaching method" or "research-based classroom teaching method", no matter which kind of teaching method it is referred to as, such method embodies the following education concepts:

First of all, students' subjectivity: Students turn into the leading characters, and at the same time, their active exploration, discovering and building of the system of the knowledge they have learned are attached to high importance. Thus the progress made in class by students help realizing development in an all-around way and the act of learning actually help them explore problems ${ }^{\mathbf{2} 2 \mathbf{I}}$.

Second, teaching interactivity: teaching activities organized by teachers contain a large number of subject discussion and group activities, some of which are carried out in class and some others after class; students set up the groups by themselves, in which, they cooperate and communicate with each other and seek common ground while putting aside differences, thus, the initiative, consciousness and creativity of the students are given full play to. Besides, through different interactive forms of internalization and externalization, promote the full development of students' knowledge, ability and quality.

Third, buildability of knowledge: teaching is the activity conducted for students to understand relevant knowledge. Points of attention shall be turned to students' internal changes, mainly the formation of students' cognition and learning structure. Teachers shall put their energy in probing into knowledge structure, and guide students in exploration of the internal relations of different knowledge and learning strategies of students, so as to allow students explore and master certain learning process and develop their own learning styles. 


\section{Main Factors Hindering Innovation of Teaching Methods in Higher Education}

Relevant policies and systems conflict with requirements of innovation of teaching methods. In many universities, evaluation of teachers, issuance of allowances are carried out in line with class hours. And in classroom assessment, teachers can only abide by the knowledge system in the textbook and "repast what the book says" one key point after another. Some evaluation standards rigidly stipulate utilization of multimedia teaching, thus the spirit of policies and systems discord with teaching requirements, which is the main obstacle restricting innovation of teaching methods in universities ${ }^{\mathbf{I} 3 \mathbf{I}}$.

Teachers are unaware of the significance and are indifferent to innovation of teaching method. Teachers lack motivation and not enthusiastic to innovation of teaching method and improvement of teaching competence. Some of them are concerned that adoption of a new teaching method may result in negative outcomes and affects their development instead. In a word, teachers fail to realize the significance of innovation of teaching method.

Students are somewhat adverse to innovation of teaching method. Under the influence of traditional teaching concepts, students tend to think the more the teacher says in a more detailed way, the better it is. From primary school to university, they have become accustomed to the teaching method by which the teacher lectures from the beginning to the end of the class, thus, they need a period of time to get used to change of the teaching method.

Limitations from teaching conditions, such as classrooms and teaching funds. In a great many of universities, the tables and chairs in the classroom are mostly fixed, thus, teachers could not organize teaching in other forms and students cannot carry out group learning in class. During the teaching process of a specific course, it is barely possible to organize extracurricular surveys or experiments. Limitations from teaching conditions on innovation of teaching method are objective and the outcomes of traditional teaching concepts ${ }^{\mathbf{4} \mathbf{I}}$.

\section{Measures taken by Teachers in Universities to Innovate Teaching Method}

1. Guide students to shift from textbook learning to subject learning and learn all academic achievements of the subjects. For the purpose of innovation of teaching method, teachers shall encourage students to learn beyond textbooks. That is to say, they can add some important monographs and journal articles in the reading materials and ask students to read, so that teaching could ignite the sparks of exchange of ideas and stimulate academic inspirations of students and teachers themselves. Therefore, it is a new starting point for innovation of teaching method to encourage students to learn beyond textbooks.

2. Allow students to carry out problem-based learning. Students is obliged to learn and master systematic knowledge, requires them to read a lot besides textbooks after class, so that they may enter into disciplinary field, build their own disciplinary knowledge system and acquire the latest disciplinary knowledge. In class, teachers shall focus on how students digest the knowledge and apply it in solving problems. Teachers raise questions and students arrange their learning according to those questions. With regard to classroom teaching, teachers shall raise questions to guide students in their learning. Only in this way, can students develop their cognition in learning of various courses, increase their professional abilities to analyze and solve problems, and can education quality be improved hereby ${ }^{\mathbf{5} \mathbf{I}}$.

3. Adopt cooperative teaching mode. Innovation of teaching method requires changing the way of individualized learning, and applying cooperative learning in classroom teaching. Cooperative learning can either be employed for problems that are hard to be solved only by one person, or the problems that can be solved by one person. The essence of cooperative learning lies in construction of a group with students acting as the members, in which, they can discuss and solve problems from different angles, and most importantly they can learn to seek common ground while putting aside differences, develop mutual understanding and mutual tolerance. Students can not only learn 
cognition but also learn to organize, express, to be tolerant, and get along well with those who have different opinions with themselves.

There definitely are other starting points for innovation of teaching method in higher education can of course, but if teachers could make some attempts, their teaching could be changed greatly, and become an intellectual activity full of joys instead of merely and giving and receiving knowledge. In that case, the teaching quality will be impeccable and beyond dispute.

\section{References}

[1]Zhang Yanfu, Innovation of Teaching Methods for Improvement of Teaching Quality in University [J], China Power Education, 2010 (18),

[2]Zhangyu, A Study on Existing Problems and Countermeasures for Evaluation of Teaching Quality of Teachers in Universities [J], Journal of Jilin Radio and TV University, 2016 (10)

[3]Zeng Dewei, On the Path Selection of Improvement of Teaching Quality in University [J], Theory and Practice of Education, 2013 (27);

[4]Zhao Wanying, Thoughts on Improvement of Monitoring of Teaching Quality in Universities [J], China Higher Education Research, 2006 (5)

[5]Huang Qiuming, A Study on Teaching Quality Monitoring and Evaluation System in Universities [J], Vocational and Technical Education, 2003 (1). 